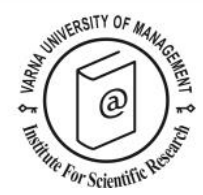

\title{
Price determinants of Airbnb listing prices in Lake Balaton Touristic Region, Hungary
}

\author{
Gábor Dudás ${ }^{1 *}$, Tamás Kovalcsik ${ }^{2}$, György Vida ${ }^{3}$, \\ Lajos Boros ${ }^{4}$ and Gyula Nagy ${ }^{5}$
}

\footnotetext{
${ }^{1}$ Centre for Economic and Regional Studies, 5600 Békéscsaba, Szabó Dezső utca 42, Hungary. Email: dudasgabor5@gmail.com

${ }^{2}$ Department of Economic and Social Geography, University of Szeged, Hungary. Email: kovalcsik.tamas@geo.uszeged.hu

3 Department of Economic and Social Geography, University of Szeged, Hungary. Email: vidagy@geo.u-szeged.hu 4 Department of Economic and Social Geography, University of Szeged, Hungary. Email: borosl@geo.u-szeged.hu 5 Department of Economic and Social Geography, University of Szeged, Hungary. Email:

geo.nagy.gyula@gmail.com
}

* Corresponding author

\begin{abstract}
The aim of the paper was to investigate the impact of different accommodation attributes on Airbnb listing prices in a touristic area. The study applied hedonic price modeling utilizing a sample of 2417 Airbnb accommodation rental offers in the Lake Balaton Touristic Region in Hungary. Our results revealed that property-related attributes significantly influence Airbnb prices although the magnitude of these effects is very diverse and complex. The OLS findings showed that the provision of air conditioning, free internet, and free parking are the main determinants of Airbnb price in the sample area, while the number of available photos and the presence of a kitchen does not significantly influence the price. The quantile regression results further demonstrated that capacity, the provision of breakfast, and TV leads to higher prices among the higher-priced accommodations, while the number of bedrooms and bathrooms, smoking, and free parking influence more the prices of lower-end accommodations.
\end{abstract}

Keywords: sharing economy, Airbnb, peer-to-peer accommodation rental, hedonic price regression, quantile regression

Citation: Dudás, G., Kovalcsik, T., Vida, G., Boros, L. and Nagy, G. (2020). Price determinants of Airbnb listing prices in Lake Balaton Touristic Region, Hungary. European Journal of Tourism Research 24, 2410.

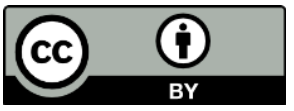




\section{Introduction}

Every night, tens of thousands of people decide not to stay in traditional accommodations like hotels but use the services of peer-to-peer $\left(\mathrm{P}_{2} \mathrm{P}\right)$ accommodation sharing platforms that allow ordinary people to rent residences to tourists. For more than a decade now, $\mathrm{P}_{2} \mathrm{P}$ accommodation sharing emerged as a major trend shaping the global tourism and hospitality industry (Guttentag \& Smith, 2017; Magno et al., 2018), disrupting the way the tourism sector is running (Bakker et al., 2018; Guttentag, 2015) and led to the complete restructuring of markets and the appearance of new travel forms (Forno \& Garibaldi, 2015; Önder et al., 2018). The rise of the phenomenon is remarkable, as the share of $\mathrm{P}_{2} \mathrm{P}$ accommodation in 2018 make up about $7 \%$ of the global accommodation supply, and the projected annual growth rate for the $\mathrm{P}_{2} \mathrm{P}$ accommodation economy is expected to be 31\% between 2013 and 2025 (Bakker et al., 2018). However, $\mathrm{P}_{2} \mathrm{P}$ accommodation rental has not necessarily created entirely new demand, as people informally renting out their residences to tourists has existed for a long time (Guttentag et al., 2018; Magno et al., 2018). But the development of Internet platforms and mobile technologies have brought many new ways of sharing and revolutionized this practice by facilitating older forms of $P_{2} \mathrm{P}$ accommodation sharing on a larger scale (Gutiérrez et al., 2017), or at least increased and made this new type of supply more visible (Önder et al., 2018).

Since its inception in 2008, Airbnb has experienced rapid growth and from a small start-up it has become the most important global player among $\mathrm{P}_{2} \mathrm{P}$ accommodation platforms with nearly 5 million listings and more than 300 million guest arrivals in 81 ooo cities in 191 countries (Airbnb, 2018). The essence and rapid success of Airbnb lies on the effective mix of several key factors, including affordable prices and economic advantages (Tussyadiah, 2015), authenticity and unique consumer experience (Guttentag, 2015; Magno et al., 2018; Tussyadiah \& Pesonen, 2016; Wang et al., 2016), sustainability (Midgett et al., 2017), flexible supply (Li \& Srinivasan, 2018), perceived attractiveness and responsiveness of the host (Ert et al., 2016; Gunter \& Önder, 2018), and the accommodation's ratings (Tussyadiah \& Zach, 2017). Above all these advantages, price and lower cost are frequently reported as one of the most important factors facilitating the rapid diffusion of $\mathrm{P}_{2} \mathrm{P}$ accommodation sharing phenomenon (Pizam, 2014; Tussyadiah \& Pesonen, 2016). As long known, price is one of the main determinants of hotel choice in tourism and hospitality industry (Lockyer, 2005), therefore, hotel room pricing is a well-researched topic (Gibbs et al., 2017). As the popularity of and demand for $\mathrm{P}_{2} \mathrm{P}$ accommodations has increased, pricing became a relevant issue in the sharing economy based accommodation sector as well, and understanding Airbnb prices became crucial both from practical and theoretical perspectives. Nevertheless, it has to be noted that as $\mathrm{P}_{2} \mathrm{P}$ rentals are privately owned apartments or houses and the vast majority of them are managed by non-professional hosts, thus, the price determining attributes and mechanism may differ from those determining hotel room price (Önder et al., 2018; Wang \& Nicolau, 2017), even though they share many common features (e.g. site and property attributes, amenities). Therefore, we think it is important to examine the impact of these accommodation attributes - which are also relevant to the traditional hotel industry - on price in the sharing economy based accommodation sector. $\mathrm{P}_{2} \mathrm{P}$ accommodation rental in its present form is relatively new, but the number of studies investigating the price determining factors and the underlying pricing strategies of this phenomenon is growing rapidly (Gibbs et al., 2017; Hrobath et al., 2017; Li et al., 2016a; Wang \& Nicolau, 2017). The majority of these studies focus mainly on larger cities, however, the importance of Airbnb is rising in popular coastal resorts and holiday destinations and regions as well (Adamiak, 2018). These regions differ in several characteristics from larger cities - e.g. the spatial patterns of supply, population distribution, the spatiality and other features of the real estate market and the housing stock, etc. Thus, the impact of $\mathrm{P}_{2} \mathrm{P}$ accommodations can be different in these regions than in large cities, but this issue is largely unexplored in the existing body of literature. Therefore, the main aim of this study 
is to shed light on the determining factors of Airbnb accommodation prices in a touristic region. For this purpose, the Lake Balaton Touristic Region in Hungary was selected for a case study.

The remainder of the paper is organized as follows: the next section reviews the related work on Airbnb and focuses on previous researches considering hedonic price theory and quantile regression. Then, the paper describes and presents the applied data and study methodology. Afterwards, the paper presents our empirical findings and finally, we conclude the paper, and discuss its limitations and present the directions for future work.

\section{Literature review}

The sharing economy and Airbnb

The sharing of goods, spaces, services, and skills among individuals is not a completely new phenomenon, but the scope of these activities was very limited in the past due to the difficulty of matching supply and demand and the lack of trust between strangers (Ranjbari et al., 2018). In the last decade, the mix of many factors such as the proliferation of the Internet and mobile technologies, globalization, urbanization, the global economic crisis, and shifts in general attitudes towards consumption and sustainability had come to cover these gaps and fostered the advent of the sharing economy (Bardhi \& Eckhardt, 2012; Mody et al., 2017; Möhlmann, 2015; Ranjbari et al., 2018). Under the "tent" of the sharing economy, these technological innovations, economic and social changes are transforming the way people produce, consume, travel, and communicate among many other activities (Alizadeh et al., 2018; Quattrone et al., 2016; Van der Borg et al., 2017) and expand traditional trading and consumption practices (Sung et al., 2018).

The phenomenon of the sharing economy appeared in the early 200os (Sung et al., 2018), however, given its exponential growth, in recent days, it is estimated that $72 \%$ of Americans (Pew Research Center, 2016) and 70\% of Europeans (OCU, 2016) are involved in sharing economy activities (Murillo et al., 2017). Furthermore, it has tremendous market potential as the revenue generated by the key sharing economy sectors are estimated to increase from \$15 billion today to roughly \$335 billion by 2025 (PWC, 2015ab). Services covered by the sharing economy range from transportation (e.g. Uber, Lyft) to accommodation (e.g. Airbnb, HomeAway) to finance (e.g. Kickstarter, Prosper) (Dudás et al., 2017b; Hamari et al., 2016; Quattrone et al., 2016). P2P marketplaces associated with the sharing economy operate particularly within the field of travel and tourism and the most popular and important player in the hospitality sector is the home sharing platform Airbnb (Boros et al., 2018; Dann et al., 2019; Dudás et al., 2017a; Guttentag, 2015; Wang \& Jeong, 2018). Airbnb, by providing access to millions of spaces from apartments and villas to castles, igloos, treehouses, or boats has recorded more than 400 million guest arrivals (Airbnb, 2018) since its launch in 2008, without owning a single room. By mid-2018, it was estimated to worth more than $\$ 38 \mathrm{bn}$ (Forbes, 2018) meaning that it is valued more than the world's largest hotel chains such as the Hilton Hotels \& Resorts, Marriott, or Hyatt (Akbar \& Tracogna, 2018; Statista, 2018). Given the exponential growth of Airbnb and its disruptive potential (Guttentag, 2015), it has received considerable scholarly attention and researchers have begun to examine a variety of issues related to Airbnb. Several studies put focus on challenges and potential threats to Airbnb's future growth (Guttentag, 2015; Meleo et al., 2016), while other address regulatory and tax issues (Guttentag, 2017; Hajibaba \& Dolnicar, 2017; Jefferson-Jones, 2015; Kaplan \& Nadler, 2015) indicating that new regulatory frameworks should be established to enable Airbnb to operate legally (Edelman \& Gerardin, 2015). More recently, many scholars have turned their attention to the impact of Airbnb on housing market and rental prices (Delgado-Medrano \& Lyon, 2016; Lee, 2016; Samaan, 2015; Wachsmuth \& Weisler, 2018) highlighting that due to the diffusion of Airbnb, entire homes and apartments are disappearing from the local housing market and this process may drive up the rents in several cities (Ke, 2017) and exclude 
residents from tourist areas (Dogru et al., 2017; Oskam \& Boswijk, 2016). Moreover, there have been many reports on the effects of Airbnb on the tourism industry (Fang et al., 2016; Gutiérrez et al., 2017; Van der Borg et al., 2017) including Airbnb's impact on hotel prices (Aznar et al., 2017; Choi et al., 2015; Neeser et al., 2015; Xie \& Kwok, 2017; Zervas et al., 2017), on hotel sales (Blal et al., 2018), on hotel occupancy rates (Ginindza \& Tichaawa, 2017), and on tourism industry employment (Fang et al., 2016). Furthermore, there were recent studies set up to explore prices and pricing decisions on Airbnb (Edelman \& Luca, 2014; Kakar et al., 2016; Teubner et al., 2017). However, given the Airbnb is primarily an urban phenomenon, empirical papers focus mainly on large cities (Gibbs et al., 2017; Wang \& Nicolau, 2017) and investigations on holiday destinations is lacking. In the following section, the paper reviews the relevant studies focusing on hotel price determinants and reveal recent findings conducted for Airbnb pricing determinants.

\section{Pricing issues in the Tourism and Hospitality industry / hedonic price regression}

Pricing is a relevant issue in the tourism and hospitality literature (Hung et al., 2010), however, the price consumers are willing to pay for an accommodation largely depends on the attributes an accommodation can offer (Castro \& Ferreira, 2015). Wang and Nicolau (2017) categorize these factors into five categories: site-specific characteristics, quality signalling factors, hotel amenities and services, property characteristics, and external factors. The effects of these attributes on price attracted significant scholarly attention by hospitality and tourism researchers in recent years, and many studies have investigated the pricing strategies in the traditional hospitality industry (Becerra et al., 2013; Castro \& Ferreira, 2018; Chen \& Rothschild, 2010; Espinet et al., 2003; Hung et al., 2010; Lee, 2016; Masiero et al., 2015; Schamel, 2012; Thrane, 2007; Yang et al., 2016; Zhang et al., 2011b).

A widely applied method for assessing the importance of these attributes is hedonic price modeling, which is credited to Rosen (1974) and is based on the idea that different price for a product or service can be viewed as composites of attributes and characteristics. Thus, the hedonic function can reveal how marketable product features will be reflected in the products market prices, in other words, it can outline, for example, how room/accommodation prices will change when characteristics of room/accommodation change (Schamel, 2012; Teubner et al., 2016; Zhang et al., 2011b). A number of recent contributions employ hedonic models, for example, Espinet, Saez, Coenders and Fluvia (2003) examined how attributes of holiday hotels in a sun-and-beach segment influence room prices and found that hotel size, distance to the beach, and the availability of free parking space have significant effect on price. Thrane (2007) applied the same approach in the city of Oslo and also showed evidence that the presence of attributes such as free parking, location, or a mini-bar are the main determinants of room rates in capital cities. Likewise, Zhang, Ye and Law (2011b) used regression models to analyse how room attributes and hotel class influence room rates in New York City hotels and revealed that hotel location and room quality are the important determinants of room prices. Chen and Rothschild (2010) analysed the impact of a variety of attributes on hotel room rates in Taipei and the empirical findings showed that hotel location, the availability of LED TV, and the presence of conference facilities have significant effects on both weekday and weekend prices. Furthermore, Schamel (2012) estimated the willingness to pay for different hotel characteristics and found that the important determining factors of hotel room prices are popularity ratings, hotel star ratings, weeks of advance booking, and certain other hotel characteristics such as express check-out, room service, and Internet access. Hung, Shang and Wang (2010), in addition, applied OLS regression supplemented with quantile regression to provide a more complex characterization of price determinants in Taiwanese hotels. The OLS results showed that number of rooms, age of hotel, and number of housekeeping staff per person are the major determining attributes of hotel room rates, while the quantile regression further refined these results and demonstrated that hotel age and market conditions are only significant in the high-priced hotel 
category. In another study, Zhang, Zhang, Lu, Cheng and Zhang (2011a) applied geographically weighted regression and examined how site and situation attributes can affect room prices in Beijing and found that star rating, hotel age, and location have the greatest influence on hotel room rates. Across these findings, the most commonly reported factors determining hotel room price are related to physical characteristics of the offerings (Gibbs et al., 2017), in addition, location and amenities - especially parking - are highlighted as further significant influencing factors.

However, while hotel room price has an important role in the traditional hospitality industry (Zhang et al., 2017), it has also a vital role in the room pricing decision of the sharing economy based accommodation rental, since price (and the possibility to save money) is one of the main influencers on the guest's accommodation selection decisions and on hosts' profits as well (Tussyadiah \& Pesonen, 2016; Zhang et al., 2017). Nevertheless, given the difference between traditional and sharing economy based accommodation products some of the price determinants of the traditional hospitability industry are unsuited for the sharing economy, therefore, new price indicators such as host characteristics (e.g. Superhost status, profile picture), special amenities, and diversified accommodation characteristics were identified to bridge this gap (Wang \& Nicolau, 2017).

As highlighted above, a significant number of studies have investigated the price determinants of hotels, but only a limited number of papers have explored what factors affect the prices of sharing economy based accommodation rentals, especially Airbnb. For example, Gutt and Herrmann (2015) examined how star ratings and rating visibility affect listing prices on the Airbnb platform and reported that rating star visibility significantly increases prices by an average of 2,69 Euro. Kakar, Franco, Voelz and Wu (2016) examined the effect of host information (e.g. race, gender, sexual orientation, etc.) on Airbnb price in San Francisco and found that Hispanic and Asian host charge lower prices (on average 9.6\% and 9.3\%) than their white counterparts, while Ert, Fleischer and Magen (2016) reported that a trustworthy photo of the host may be associated with higher listing price and the higher probability of being chosen. Li, Pan, Yang and Guo (2016b) analysed that how the distance to the nearest landmark, the impact of a facility, and the popularity of the nearest landmark affect Airbnb prices and proved positive effects. Hrobath, Leisch and Dolnicar (2017) identified the drivers of price on entire properties in Vienna and found that location is the primary driver of prices and properties with more amenities charge higher prices. Teubner, Hawlitschek and Dann (2017) quantified the price effects of reputation features using a large scale dataset from 86 German cities and found that indexes such as hosts' ranking scores and duration of membership are associated with economic value. Similarly, Gibbs, Guttentag, Gretzel, Morton and Goodwill (2017) examined the impact of a variety of attributes on the rates of Airbnb by using the listings information in five Canadian areas reporting that physical characteristics, location, and host characteristics significantly affect prices. Likewise, Wang and Nicolau (2017) in their study investigated Airbnb rental offers in 33 cities by using OLS and quantile regression through the analysis of 25 explanatory variables and highlighted the relationship between these attributes and accommodation price.

In summary, the number of studies on pricing issues of sharing economy based accommodation rentals is growing rapidly, however, these focus primarily on large cities, therefore Airbnb's impact on larger touristic regions remains unclear. The remaining part of the paper aims to bridge this gap.

\section{Methodology and data}

\section{Study area}

The area selected for this study was the Lake Balaton Touristic Region in Hungary. We choose this holiday destination area for several reasons. First, Lake Balaton is the greatest lake in Central Europe, 
and the oldest and most established tourist destination in Hungary (Puczkó \& Rátz, 20oo; Törzsök et al., 2017). In 2017, the region hosted more than 2.4 million tourists and the number of overnight stays totaled 8 million (33\% of them international stays), with an average stay of 3.2 nights (CSO, 2019), generating a huge demand for accommodation services. Thus, behind the Hungarian capital Budapest, Lake Balaton is the second most visited tourist area in Hungary (Domonkos et al., 2016). Second, the phenomenon of locals renting out their homes or rooms for tourist exists in the region for decades and it became a widespread practice. This long-standing tradition is represented in the capacity of accommodation supply as well, namely, in 2018, 615 commercial accommodation establishments offered more than 94 thousand bed places, while more than 19 ooo private accommodation establishments (short-term rentals) offered more than 108 thousand bed places in the region (CSO, 2019). These numbers may also highlight, that unlike large cities, $\mathrm{P}_{2} \mathrm{P}$ accommodation rental in this region can be built on existing stocks of holiday homes, and create an extensive capacity for the supply side of sharing economy based accommodation rental and may scale it dramatically and raise it to a new level. As a result, Airbnb became a major actor in the hospitality industry in the region and can provide an appropriate study area and an important benchmark for other Airbnb studies.

\section{Data and variables}

The region - according to Hungarian law [1] - consists of 180 settlements and the study was based on Airbnb listings from this area. The database was compiled by applying web-scraping technology to gather publicly available information directly from the Airbnb website. Web-scraping is an innovative and more frequently applied data collecting method (Gibbs et al., 2017; Gunter \& Önder, 2018; Horn \& Merante, 2017; Smith et al., 2018) and its essence lies in that a web-crawler (computer program) visits the selected website and based on specified parameters saves the information displayed on the site into a database for further analysis (Gyódi, 2017; Olmedilla et al., 2016). The data was collected for July 2018 and Table 1 presents a brief description of the sample and the variables reporting a total of 2417 listings of the region. Descriptive statistics of the sample highlight that the average rental price for the sampled Airbnb listings is $\$ 89.49$, however, offers cover a wide spectrum of different listing prices within the region indicated by the high standard deviation values. The predominant room types are entire homes or apartments accounting for the largest proportion (86\%), followed by private rooms (14\%) and shared rooms represent only a marginal share (less than $1 \%$ ). The main characteristics of the Airbnb inventory in the region are the follows: $94 \%$ have a kitchen; $70 \%$ offer free wireless internet access and $88 \%$ have a TV; only $7 \%$ offer breakfast and 30\% are equipped with air conditioning; smoking is not allowed in $67 \%$ of the accommodations.

\section{Data analysis}

The hedonic pricing method, widely credited to Rosen (1974), is based on the idea that different price for a product or service can be viewed as composites of attributes and characteristics. Thus, the hedonic function can reveal how marketable product features will be reflected in the products market prices, in other words, it can outline, for example, how room/accommodation prices will change when characteristics of room/accommodation change (Schamel, 2012; Teubner et al., 2016; Zhang et al., 2011b). To assess the accommodation attributes' economic value and quantify the individual impact of certain features on Airbnb accommodation price, we conducted hedonic price regression supplemented with quantile regression $(\mathrm{QR})$ analysis to reveal the nexuses between a dependent variable and a set of predictor variables. As a dependent variable price per person per night (in a logarithmic form) was selected, while the independent variables are described in Table1. Hedonic price regression was based 
Table 1. Brief description of the variable list $(n=2417)$

\begin{tabular}{|c|c|c|c|}
\hline Variable name & Description of variable/attribute & $\begin{array}{l}\text { Mean/ } \\
\text { proportion }\end{array}$ & $\begin{array}{l}\text { Standard } \\
\text { deviation }\end{array}$ \\
\hline PRICE & Listed price per night (In US dollars) & 89.49 & 83.91 \\
\hline LnPRICE & Price, logged & 4.25 & 0.67 \\
\hline DISTANCE & $\begin{array}{l}\text { Distance between the location of the Airbnb } \\
\text { accommodation and the lakeside (in } \mathrm{km} \text { ) }\end{array}$ & 2.26 & 3.96 \\
\hline $\begin{array}{l}\text { ENTIRE } \\
\text { HOME/APT }\end{array}$ & Entire home/apartment (Dummy variable) & 0.86 & 0.35 \\
\hline PRIVATE ROOM & Private room (Dummy variable) & 0.14 & 0.35 \\
\hline SHARED ROOM & Shared room (Dummy variable) & 0.005 & 0.07 \\
\hline CAPACITY & $\begin{array}{l}\text { The number of people that can be } \\
\text { accommodated }\end{array}$ & $5 \cdot 55$ & 2.94 \\
\hline BEDROOMS & The number of bedrooms & 2.32 & 1.43 \\
\hline BED NUMBER & The number of beds & 4.35 & 3.17 \\
\hline BATHROOMS & The number of bathrooms & 1.53 & 1.05 \\
\hline KITCHEN & Kitchen is available (Dummy variable) & 0.94 & 0.25 \\
\hline BREAKFAST & Offer breakfast (Dummy variable) & 0.07 & 0.25 \\
\hline INTERNET & $\begin{array}{l}\text { Free wireless internet access (Dummy } \\
\text { variable) }\end{array}$ & 0.70 & 0.46 \\
\hline TV & Offer a TV (Dummy variable) & 0.88 & 0.33 \\
\hline AIR & Offer Air Conditioning (Dummy variable) & 0.30 & 0.46 \\
\hline \multicolumn{4}{|l|}{ CONDITIONING } \\
\hline FREE PARKING & Offer free parking (Dummy variable) & 0.84 & 0.37 \\
\hline POOL & Offer a pool (Dummy variable) & 0.19 & 0.39 \\
\hline PHOTOS & Number of photos about the accommodation & $17 \cdot 53$ & 11.35 \\
\hline SMOKING & Smoking is not allowed (Dummy variable) & 0.67 & 0.47 \\
\hline
\end{tabular}

on the conditional mean of the dependent variable, estimating the average response of the independent variable to changes in the explanatory variables (Wang \& Nicolau, 2017). In doing so, the following equation representing the general hedonic model was formulated:

$\ln \left(\mathrm{P}_{\mathrm{i}}\right)=\alpha+\sum_{\mathrm{k}} \beta_{\mathrm{k}} \mathrm{X}_{\mathrm{ki}}+\varepsilon_{\mathrm{i}}$

where $\ln \left(\mathrm{P}_{\mathrm{i}}\right)$ is the embodiment of the natural logarithmic transformation of the price per person per night linked with booking $i, \alpha$ is a constant term, the coefficients $\beta_{\mathrm{k}}$ are the implicit prices for Airbnb attributes linked with the $\mathrm{k}$-th independent variable $\mathrm{x}_{\mathrm{ki}}$ representing the associated Airbnb characteristics, while $\varepsilon$ is Normal error (Hung et al., 2010; Masiero et al., 2015; Schamel, 2012). Many authors suggest that multicollinearity may be a problematic issue in hedonic models (Andersson, 2010; Yang et al., 2016). Thus, to address this issue, we calculated the Variance Inflation Factor (VIF) to detect the seriousness of multicollinearity. According to Kennedy (2018), multicollinearity is a serious problem if the VIF value is above ten. In this study, all the VIF values were below the commonly used threshold point of 10 - the highest VIF value was 4.49 - indicating that multicollinearity is not a problematic issue in the present study. Moreover, we have to keep in mind, when assessing the effect of a dummy independent variable on a log-dependent variable in a log-linear hedonic pricing regression that we have to transform the coefficient by $\left(e^{\beta}-1\right)$, where $\beta$ is the coefficient and $e$ is the base of natural logarithm (Gibbs et al., 2017; Halvorsen \& Palmquist, 1980), and this gives the estimated effect of the dummy variables in percentage terms. 
However, the hedonic pricing model may give an incomplete description of the conditional distribution (Hung et al., 2010; Mosteller \& Tukey, 1977) as it only considers the average relationship between price and the other explanatory variables. Therefore, to move beyond the analysis of the conditional mean of the dependent variable and provide information about the higher and lower tail behaviour of the distribution, quantile regression was also applied. In addition to hedonic price regression, QR measures the effects of individual explanatory variables on the whole distribution of the dependent variable and may reveal the hidden price-response patterns (Wang \& Nicolau, 2017) and further increases the interpretability of the results (Masiero et al., 2015). According to Koenker (2005), quantile regression was specified as follows:

Presuming that $\mathrm{Y}$ is a real value random variable with a cumulative distribution function $\mathrm{F}_{\mathrm{Y}}(\mathrm{y})=\mathrm{P}(\mathrm{Y} \leq$ $\mathrm{y})$, the $\tau$ th quantile of $\mathrm{Y}$ can be given by

$\mathrm{Q}_{\mathrm{Y}}(\tau)=\inf \left\{\mathrm{y}: \mathrm{F}_{\mathrm{Y}}(\mathrm{y}) \geq \tau\right\}$

where $0<\tau<1$.

\section{Results and discussion}

Table 2 reports the results of the OLS including the effects of the independent variables (in percent) on price and presents the estimated coefficients at the $10^{\text {th }}, 25^{\text {th }}, 50^{\text {th }}, 75^{\text {th }}$, and $90^{\text {th }}$ quantiles of the quantile regression analysis. All the selected dependent variables of the general OLS analysis have a significant effect on Airbnb price except 'kitchen' and 'photo', while the quantile regression results are showing us mixed and more complex and sophisticated results.

Looking first at the variable distance, it is outlined, that consistent with previous studies (Gibbs et al., 2017; Wang \& Nicolau, 2017) location of the Airbnb rental has significant negative effect on price, indicating that with each additional kilometer the accommodation is located away from the lakeside, the price decreases with $2.55 \%$. The pattern of the quantile parameters signifies that the negative effect of distance is greater for lower-priced rentals (Table 3 ).

The OLS regression estimates that the room type entire home/apt has a noteworthy significant positive impact on price associated with an increase of $17.87 \%$, indicating that an entire home leads to higher prices. Moreover, the numbers of the quantile regression provide richer information reflecting a decreasing pattern, thus, highlighting that the influence of this attribute is higher in the lower-priced accommodations and lower for the higher-priced accommodations, while at the $90^{\text {th }}$ quantile it has an insignificant effect on accommodation price.

The attributes related to the size of the rentals - such as capacity, bedroom number, bed count, and bathroom number - have mixed effects on price. From the OLS results capacity and bedroom number signifies sizeable positive influence, while somewhat unexpectedly, bed number and bathroom number are negatively related to rental price, which is inconsistent with previous findings. More specifically, capacity - which embodies the number of people that can be accommodated - exhibit that each increase in capacity (person) may result in a price increase of $10.8 \%$ and each additional bedroom can give rise to Airbnb price by $8.69 \%$. In other words, the accommodation is more expensive if it accommodates more people and has more bedrooms. Although this result was foreseeable, quantile estimates highlight the positive impact of capacity on price is consistently stronger for the higher priced-listings, while in contrast, bedroom number affects lower-priced hotels much more. Furthermore, the OLS regression for 
Table 2. Estimated results of OLS and quantile regression

\begin{tabular}{|c|c|c|c|c|c|c|c|}
\hline Variable & OLS & Diff (\%) & 0.1 & 0.25 & 0.5 & 0.75 & 0.9 \\
\hline $\begin{array}{l}\text { DISTANCE } \\
\text { ENTIRE }\end{array}$ & $-0.026^{* * *}$ & -2.555 & $-0.0336^{* * *}$ & $-0.0254^{* * *}$ & $-0.0193^{* * *}$ & $-0.0244^{* * *}$ & $-0.0184^{* * *}$ \\
\hline HOME/APT & $0.164^{* * *}$ & 17.869 & $0.24812^{* * *}$ & $0.1592^{* *}$ & $0.1522^{* * *}$ & $0.0996^{*}$ & -0.0145 \\
\hline CAPACITY & $0.096^{* * *}$ & 10.076 & $0.0346^{*}$ & $0.0901^{* * *}$ & $0.1041^{* * *}$ & $0.1273^{* * *}$ & $0.1416^{* * *}$ \\
\hline BEDROOMS & $0.083^{* * *}$ & 8.692 & $0.1353^{* * *}$ & $0.0777^{* * *}$ & $0.0679^{* * *}$ & $0.0727^{* * *}$ & $0.0534^{*}$ \\
\hline BED NUMBER & $-0.034^{* * *}$ & $-3 \cdot 313$ & -0.0169 & $-0.0285^{* * *}$ & $-0.0208^{* * *}$ & $-0.0271^{* * *}$ & $-0.0425^{* * *}$ \\
\hline BATHROOMS & $-0.056^{* *}$ & $-5 \cdot 424$ & $-0.1371^{* * *}$ & $-0.1077^{* * *}$ & $-0.0386^{* *}$ & -0.0235 & 0.0173 \\
\hline KITCHEN & -0.050 & -4.841 & -0.0718 & -0.0282 & $-0.0938^{*}$ & -0.0861 & -0.0802 \\
\hline BREAKFAST & $0.127^{*}$ & $13.55^{0}$ & 0.0943 & 0.106 & $0.1117^{* *}$ & $0.1728^{* *}$ & $0.2024^{* *}$ \\
\hline INTERNET & $0.171^{* * *}$ & 18.666 & $0.1189^{*}$ & $0.1706^{* * *}$ & $0.1429^{* * *}$ & $0.1625^{* * *}$ & $0.1557^{* * *}$ \\
\hline $\begin{array}{l}\text { TV } \\
\text { AIR }\end{array}$ & $-0.151^{* * *}$ & -14.047 & 0.0992 & -0.0353 & $-0.1553^{* * *}$ & $-0.2035^{* * *}$ & $-0.2305^{* * *}$ \\
\hline CONDITIONING & $0.317^{* * *}$ & $37 \cdot 367$ & $0.2892^{* * *}$ & $0.2779^{* * *}$ & $0.3373^{* * *}$ & $0.3489^{* * *}$ & $0.3425^{* * *}$ \\
\hline FREE PARKING & $-0.206^{* * *}$ & -18.599 & $-0.3041^{* * *}$ & $-0.2228^{* * *}$ & $-0.1989^{* * *}$ & $-0.1577^{* * *}$ & $-0.1074^{*}$ \\
\hline POOL & $0.137^{* * *}$ & 14.661 & $0.1176^{*}$ & $0.1268^{* *}$ & $0.1194^{* * *}$ & $0.2012^{* * *}$ & $0.1274^{* *}$ \\
\hline PHOTOS & 0.001 & 0.108 & -0.0029 & $-0.0029^{*}$ & -0.0015 & $0.0025^{*}$ & $0.0049^{* *}$ \\
\hline SMOKING & $-0.156^{* * *}$ & -14.403 & $-0.3066^{* * *}$ & $-0.3008^{* * *}$ & $-0.1522^{* * *}$ & -0.0510 & -0.1308 \\
\hline
\end{tabular}

Notes: ${ }^{*}$ denotes $\mathrm{p}<0,05,{ }^{* *}$ denotes $\mathrm{p}<0,01,{ }^{* * *}$ denotes $\mathrm{p}<0,001$

Table 3. Significant differences among quantiles ( $p$-values)

\begin{tabular}{lllll}
\hline Variable & $\mathbf{0 . 1 , 0 . 2 5}$ & $\mathbf{0 . 2 5}, \mathbf{0 . 5}$ & $\mathbf{0 . 5}, \mathbf{0 . 7 5}$ & $\mathbf{0 . 7 5}, \mathbf{0 . 9}$ \\
\hline DISTANCE & 0.086 & 0.016 & 0.183 & 0.077 \\
ENTIRE & & & & \\
HOME/APT & 0.198 & 0.895 & 0.282 & 0.019 \\
CAPACITY & 0.005 & 0.339 & 0.066 & 0.198 \\
BEDROOMS & 0.105 & 0.685 & 0.834 & 0.486 \\
BED NUMBER & 0.321 & 0.473 & 0.600 & 0.118 \\
BATHROOMS & 0.346 & 0.013 & 0.658 & 0.077 \\
KITCHEN & 0.624 & 0.348 & 0.876 & 0.892 \\
BREAKFAST & 0.910 & 0.942 & 0.478 & 0.774 \\
INTERNET & 0.201 & 0.393 & 0.554 & 0.874 \\
TV & 0.216 & 0.003 & 0.245 & 0.589 \\
AIR & & & & \\
CONDITIONING & 0.832 & 0.020 & 0.730 & 0.223 \\
FREE PARKING & 0.061 & 0.349 & 0.276 & 0.235 \\
POOL & 0.870 & 0.863 & 0.064 & 0.010 \\
PHOTOS & 0.992 & 0.055 & 0.505 & 0.203 \\
SMOKING & 0.883 & 0.000 & 0.000 & 0.478 \\
\hline
\end{tabular}


the number of beds and the number of bathrooms gives significant negative coefficients indicating that an additional bed results in a price decrease of $3.31 \%$, while each additional bathroom is associated with a price decrease of $5.42 \%$. The results of the quantile regression further indicate that bed number does not significantly influence accommodation price in the $10^{\text {th }}$ quantile and the $25^{\text {th }} 50^{\text {th }}$ and $75^{\text {th }}$ quantile parameters take higher values than the goth. The quantile estimates for bathroom number illustrate that coefficients of the $75^{\text {th }}$ and $90^{\text {th }}$ quantile are insignificant, while those for $10^{\text {th }}, 25^{\text {th }}$ and $50^{\text {th }}$ are significant, outlining that the provision of bathrooms leads to lower the prices at the lower-end accommodations ( $10^{\text {th }}$ and $25^{\text {th }}$ quantile).

Considering the variable kitchen, no significant effect on price can be outlined according to the results of both the OLS and the QR analysis, except the $50^{\text {th }}$ quantile where the price is negatively influenced. The reason that the provision of kitchen is not significant might be that most of the accommodations (94\%) are equipped with a kitchen, therefore, it is considered to be a basic service that is not reflected in the price of the accommodation.

The provision of breakfast has a positive and significant impact on price and host may charge $13.55 \%$ more, if the accommodation provides this service. However, when quantile regression is evaluated at the lower-priced accommodations ( $10^{\text {th }}$ and $25^{\text {th }}$ quantile), the provision of breakfast does not significantly influence price, but it is significant for the $50^{\text {th }}, 75^{\text {th }}$, and $90^{\text {th }}$ quantile. This is inconsistent with previous findings (Wang \& Nicolau, 2017), but during the interpretation of the results we have to note, that only $7 \%$ of the listings offer breakfast, so this minority group may charge higher prices in accommodations, which are priced above average, presumably for please their guest and make the rental more appealing by offering breakfast as an extra amenity.

The provision of air conditioning has the largest positive and significant influence on price in the sample. The rates for apartments equipped with air conditioning are priced $37.37 \%$ higher than those without this amenity. The quantile coefficients indicate a mixed pattern highlighting that the influence of this attribute is lower for the lower-priced accommodations and higher for the higher-priced accommodations reaching its top in the $75^{\text {th }}$ quantile. These findings support that in a holiday destination air conditioning is the comfort function (being the most important in the summer) in an accommodation for which people usually have to pay the most.

Regarding the free wireless internet access, the OLS estimated a significant and positive influence on the listed price associated with a price increase of $18.67 \%$ in those rooms which have such access. In addition, the coefficients of the quantile estimates highlight different magnitudes as we move up the conditional distribution signifying that accommodations in the lowest-priced quantile do not charge as much for free internet as their higher-priced $\left(50^{\text {th }}, 75^{\text {th }}\right.$, and $90^{\text {th }}$ quantile) competitors, however, the $25^{\text {th }}$ quantile listings increase the price most in order to have free internet access.

Between the amenities that were considered, the provision of TV and free parking have a significant negative effect on price. The OLS regression stresses that rates for accommodations equipped with a TV are about $\mathbf{1 4 . 0 8 \%}$ less than those without such appliances. However, quantile estimates signify that the effect of this variable is not significant for the $10^{\text {th }}$ and $25^{\text {th }}$ quantile, while coefficients of the other three quantile highlight that the presence of a TV is less important among the higher-priced listings. The amenity free parking has also a significant negative impact on prices with decreasing values in the quantile coefficients. The OLS result highlight the presence of a free parking spot is associated with a price decrease of $18.6 \%$ while the quantile estimates outline that the negative effect is higher for the lower-priced accommodations and lower for the higher priced ones. These results are inconsistent with 
previous findings on hotel price determinants (Espinet et al., 2003; Thrane, 2007) and Airbnb price determinants (Wang \& Nicolau, 2017) showing that the provision of this attribute in a touristic region may have a quite different effect than the same variable for a hotel or an Airbnb accommodation in a city region.

The provision of pool is associated with significant price increase of $14.66 \%$ while quantile coefficients are relatively constant except the $75^{\text {th }}$ quantile where positive impact of this amenity is the highest. The number of available photos about the accommodation does not significantly influence listing price according to the results of the OLS, however quantile estimates coefficients vary over the conditional distribution signifying that the $10^{\text {th }}$ and $50^{\text {th }}$ quantile are insignificant, the $25^{\text {th }}$ quantile is significant but negatively affect accommodation price, while the $75^{\text {th }}$ and $90^{\text {th }}$ quantile are significant with positive impact on price, although the degree of this effect is very low.

Finally, the attribute smoking has also a significant negative effect, thus in those apartments where smoking is allowed host charge $\mathbf{1 4 . 4 0} \%$ less than in those where smoking is not permitted. The quantile estimates highlight that the negative effect is stronger at the lower-tail apartments, however, the coefficients for the $75^{\text {th }}$ and $90^{\text {th }}$ quantile are insignificant. The results are consistent with previous findings (Wang \& Nicolau, 2017) and strengthen the assumption that hosts are trying to make their (smoking)homes more attractive by lowering their prices.

\section{Conclusions}

In the present article, we have investigated whether and how accommodation attributes are associated with Airbnb accommodation prices in a touristic region and quantified these effects by applying OLS and quantile regression analysis. In line with previous studies, the findings confirm that propertyrelated attributes significantly influence Airbnb prices in a touristic region as well, although the magnitude of these effects is very diverse and complex.

The OLS results showed that the provision of air conditioning, free internet, and free parking are the main determinants of Airbnb price in the sample area, while the number of available photos and the presence of a kitchen does not significantly influence the price. The quantile regression results further demonstrated that capacity, the provision of breakfast and TV leads to higher prices among the higherpriced accommodations, while the number of bedrooms and bathrooms, smoking, and free parking influence more the prices of lower-end accommodations.

\section{Findings consistent with previous studies}

Our results also illustrate that several factors have similar effects with previous findings. The attributes related to the size of the rentals such as capacity and bedroom number are associated with higher rental prices in various cities (Cai et al., 2019; Chen \& Xie, 2017; Gibbs et al., 2018; Kakar et al., 2016; Wang \& Nicolau, 2017) and according to our results the listings in the Lake Balaton Tourism Region are no exception. As expected, entire homes also account for significant price increase. As most previous studies indicated, location greatly matters both in the case of hotels (Espinet et al., 2003; Thrane, 2007; Zhang et al., 2011a) and Airbnb rentals (Gibbs et al., 2018; Perez-Sanchez et al., 2018; Wang \& Nicolau, 2017; Zhang et al., 2017) as well, and so is the case in the Lake Balaton Region. The smoking allowance is negatively related to Airbnb price in the study area, which is also in line with previous findings (Kennedy et al., 2018; Wang \& Nicolau, 2017), emphasizing that hosts are trying to lower their prices to make their (smoking)homes more attractive. 
Findings different from previous studies

Surprisingly, in contrast with previous studies, the number of beds and the number of bathrooms have negative influence on price challenging the findings found for Airbnb listings located in major cities (Cai et al., 2019; Chen \& Xie, 2017; Gibbs et al., 2018; Wang \& Nicolau, 2017). These two factors may indicate that listings in the Lake Balaton Tourism Region have different inner characteristics than the listings in large cities, thus, host take them differently into consideration during their price setting. It was also inconsistent with previous research (Gibbs et al., 2018; Perez-Sanchez et al., 2018), that the number of photos does not have a significant effect on price in general as in - only in the $75^{\text {th }}$ and $90^{\text {th }}$ quantile can be a very low positive impact outlined -, although pictures are perceived as important in building trust (Ert et al., 2016; Teubner et al., 2017) and may be a good indicator of professionalism (Gibbs et al., 2018). The next finding inconsistent with previous findings lies in the effect of free parking. Both hotel research (Espinet et al., 2003; Thrane, 2007) and Airbnb research (Cai et al., 2019; Gibbs et al., 2018; Wang \& Nicolau, 2017) states, that free parking is associated with higher prices in various cities. However, our results highlight, that in a touristic region due to different spatial and settlement structure, free parking may have a significantly different effect on Airbnb rental prices than in large cities.

\section{Limitations and directions for future research}

Nevertheless, this study contributes to the existing literature on the price determinants of sharing economy based accommodation rentals. Practically, the analysis may offer potential implications for stakeholders of the traditional accommodation industry such as managers, decision makers, accommodation suppliers to analyse and evaluate their market situation and strategies and improve their services. Moreover, the present paper may provide hosts with insights how to set up their pricing strategies to increase their revenues, and may help Airbnb employees to design tools and guides that can offer hints and tips for hosts for ideal price setting.

We acknowledge that like any piece of research, this study has certain limitations that need to be highlighted. First, it is temporally limited as only one time period is considered (July 2018), therefore seasonal differences are missing from the analysis, which needs to be addressed in future studies. Second, the research is geographically limited as the study focused on an exclusive sample area, namely, the Lake Balaton Touristic Region, Hungary. Therefore, variations between cities or even regions have not been fully explored, nevertheless, the study provides insight into that certain accommodation attributes how may affect Airbnb price in a touristic region. Another limitation is that the research scrutinizes the accommodation attributes affecting accommodation price and the social, economic, and psychological factors determining the host price-setting strategies are not considered.

In conclusion, the present research provides relevant insights, however, it underscores the need for further research. Specifically, future research should expand the time-period and research scope focusing on the difference in price-determinant nexuses between regions and various city-types. It would be also important to conduct an analysis to reveal the price-setting differences between professional and non-professional hosts.

\section{Endnotes}

[1]: The list of settlements is set out in the T/18783 Bill of 2017 Urban Planning Plan for Hungary and certain priority areas (http://www.parlament.hu/irom4o/18783/HTMLT18783.pdf) 


\section{Acknowledgments}

The research has been implemented with the support provided from National Research, Development and Innovation Fund of Hungary (grant number PD128015), financed under the 'Geographical examination of peer-to-peer accommodations in Hungary' funding scheme.

\section{References}

Adamiak, C. (2018). Mapping Airbnb supply in European cities. Annals of Tourism Research, 71(C), 6771.

Airbnb (2018). Fast Facts. URL: https://press.atairbnb.com/fast-facts/ (Accessed o6.06.2018).

Akbar, Y. H. \& Tracogna, A. (2018). The sharing economy and the future of the hotel industry: Transaction cost theory and platform economics. International Journal of Hospitality Management, 71, 91-101.

Alizadeh, T., Farid, R. \& Sarkar, S. (2018). Towards Understanding the Socio-Economic Patterns of Sharing Economy in Australia: An Investigation of Airbnb Listings in Sydney and Melbourne Metropolitan regions. Urban Policy and Research, 1-19.

Andersson, D. E. (2010). Hotel attributes and hedonic prices: an analysis of internet-based transactions in Singapore's market for hotel rooms. The Annals of Regional Science, 44(2), 229-240.

Aznar, J. P., Sayeras, J. M., Rocafort, A. \& Galiana, J. (2017). The irruption of Airbnb and its effects on hotel profitability: An analysis of Barcelona's hotel sector. Intangible Capital, 13(1), 147-159.

Bakker, M., Twining-Hard, L., Cordova Lopez, J. E., Gössling, S., Li, W., Nevill, H., Rinne, A., Salern, T., Shahidsaless, R. \& Shiels, D. (2018). Tourism and the Sharing Economy: Policy \& Potential of Sustainable Peer-to-Peer Accommodation. The World Bank Group. URL: http://documents.worldbank.org/curated/en/161471537537641836/pdf/130054-REVISED-Tourismand-the-Sharing-Economy-PDF.pdf (Accessed 10.10.2018).

Bardhi, F. \& Eckhardt, G. (2012). Access-based consumption: The case of car sharing. Journal of Consumer Research, 39(4), 881-898.

Becerra, M., Santaló, J. \& Silva, R. (2013). Being better vs. being different: differentiation, competition, and pricing strategies in the Spanish hotel industry. Tourism Management, 34, 71-79.

Blal, I., Singal, M. \& Templin, J. (2018). Airbnb's effect on hotel sales growth. International Journal of Hospitality Management, 73, 85-92.

Boros, L., Dudás, G., Kovalcsik, T., Papp, S. \& Vida, Gy. (2018). Airbnb in Budapest: Analysing spatial patterns and room rates of hotels and peer-to-peer accommodations. GeoJournal of Tourism and Geosites, 21(1), 26-38.

Cai, Y., Zhou, Y., Ma, J. \& Scott N. (2019). Price determinants of Airbnb listings: Evidence from Hong Kong. Tourism Analysis, 42, 227-242.

Castro, C. \& Ferreira, F. A. (2015). Effects of Hotel Characteristics on Room Rates in Porto: A Hedonic Price Approach. AIP Conference Proceedings, 1648(1), 1-5.

Castro, C. \& Ferreira, F. A. (2018). Online hotel ratings and its influence on hotel room rates: the case of Lisbon, Portugal. Tourism \& Management Studies, 14(1), 63-72.

Chen, Y. \& Xie, K. (2017). Consumer valuation of Airbnb listings: A hedonic pricing approach. International Journal of Contemporary Hospitality Management, 29(9), 2405-2424.

Chen, C-F. \& Rothschild, R. (2010). An application of hedonic pricing analysis to the case of hotel rooms in Taipei. Tourism Economics, 16(3), 685-694.

Choi, K-H., Jung, J., Ryu, S., Kim, S-D. \& Yoon, S-M. (2015). The relationship between Airbnb and the Hotel Revenue: In the Case of Korea. Indian Journal of Science and Technology, 8(26), 1-8.

CSO-Hungarian Central Statistical Office (2019). Dissemination database. URL: http://statinfo.ksh.hu/Statinfo/themeSelector.jsp?\&lang=en (Accessed o7.07.2019) 
Dann, D., Teubner, T. \& Weinhardt, C. (2019). Poster child and guinea pig - insights from a structured literature review on Airbnb. International Journal of Contemporary Hospitality Management, 31(1), 427-473.

Delgado-Medrano, H. M. \& Lyon, K. (2016). Short Changing New York City - The impact of Airbnb on New York City's housing market. BJH Advisors LLC. URL: http://www.hccnyc.org/documents/ShortchangingNYC2016FINALprotected_ooo.pdf (Accessed 10.10.2018)

Dogru, T., Mody, M. \& Suess, C. (2017). Comparing apples and oranges? Examining the impacts of Airbnb on hotel performance in Boston. Boston Hospitality Review. URL: http://www.bu.edu/bhr/2017/o6/o7/airbnb-in-boston/ (Accessed 10.10.2018).

Domonkos, Á., Sinkovics, K. \& Retz, T. (2016). Turizmusgazdaság a Balaton idegenforgalmi régióban (Tourism industry in Balaton Touristic Region). Területi Statisztika, 56(3), 346-386.

Dudás, G., Boros, L., Kovalcsik, T. \& Kovalcsik, B. (2017a). The visualisation of the spatiality of Airbnb in Budapest using 3-band raster representation. Geographica Technica, 12(1), 23-30.

Dudás, G., Vida, Gy., Kovalcsik, T. \& Boros, L. (2017b). A socio-economic analysis of Airbnb in New York City. Regional Statistics, 7(1), 135-151.

Edelman, B. G. \& Gerardin, D. (2015). Efficiencies and Regulatory Shortcuts: How Should We Regulate Companies like Airbnb and Uber? Stanford Technology Law Review, 19, 293-328.

Edelman, B. G. \& Luca, M. (2014). Digital discrimination: The case of Airbnb.com. Harvard Business School Working Paper No.14-054.

Ert, E., Fleischer, A. \& Magen, N. (2016). Trust and reputation in the sharing economy: The role of personal photos in Airbnb. Tourism Management, 55, 62-73.

Espinet, J. M., Saez, M., Coenders, G. \& Fluvia, M. (2003). Effect on prices of the attributes of holiday hotels: a hedonic prices approach. Tourism Economics, 9(2), 165-177.

Fang, B., Ye, Q. \& Law, R. 2016. Effect of Sharing Economy on Tourism Industry Employment. Annals of Tourism Research, 57, 264-267.

Forbes (2018). As a rare profitable unicorn, Airbnb appears to be worth at least $\$ 38$ billion. URL: https://www.forbes.com/sites/greatspeculations/2018/o5/11/as-a-rare-profitable-unicorn-airbnbappears-to-be-worth-at-least-38-billion/ (Accessed 10.10.2018).

Forno, F. \& Garibaldi, R. (2015). Sharing Economy in Travel \& Tourism: The Case of Home-Swapping in Italy. Journal of Quality Assurance in Hospitality \& Tourism, 16(2), 202-220.

Gibbs, C., Guttentag, D., Gretzel, U., Morton, J. \& Goodwill, A. (2017). Pricing in the sharing economy: a hedonic pricing model applied to Airbnb listings. Journal of Travel E Tourism Marketing, 35(1), 4556.

Ginindza, S. \& Tichaawa, T. M. (2017). The impact of sharing accommodation on the hotel occupancy rate in the kingdom of Swaziland. Current Issues in Tourism, 1-17.

Gunter, U. \& Önder, I. (2018). Determinants of Airbnb demand in Vienna and their implications for the traditional accommodation industry. Tourism Economics, 24(3), 270-293.

Gutiérrez, J., García-Palomares, J. C., Romanillos, G. \& Salas-Olmedo, M. H. (2017). The eruption of Airbnb in tourist cities: Comparing spatial patterns of hotels and peer-to-peer accommodation in Barcelona. Tourism Management, 62, 278-291.

Gutt, D. \& Herrmann, P. (2015). Sharing Means Caring? Hosts' Price Reaction to Rating Visibility. ECIS 2015 Research-in-Progress Papers. Paper 54. URL: https://aisel.aisnet.org/ecis2015_rip/54 (Accessed 10.10.2018).

Guttentag, D. (2015). Airbnb: Disruptive Innovation and the Rise of an Informal Tourism Accommodation Sector. Current Issues in Tourism, 18(12), 1192-1217.

Guttentag, D. (2017). Regulating Innovation in the Collaborative Economy: An Examination of Airbnb's Early Legal Issues. In: Dredge, D., Gyimóthy, Sz. (eds.): Collaborative Economy and Tourism. Tourism on the Verge, Springer, Cham. 97-128. 
Guttentag, D. \& Smith, S. (2017). Assessing Airbnb as a disruptive innovation relative to hotels: Substitution and comparative performance expectation. International Journal of Hospitality Management, 64, 1-10.

Guttentag, D., Smith, S., Potwarka, L. \& Havitz, M. (2018). Why Tourist Choose Airbnb: A MotivationBased Segmentation Study. Journal of Travel Research, 57(3), 342-359.

Gyódi, K. (2017). Airbnb and the Hotel Industry in Warsaw: An Example of Sharing Economy? Central European Economic Journal, 2(49), 23-34.

Hajibaba, H. \& Dolnicar, S. (2017). Regulatory Reactions around the World. In: Dolnicar, S. (ed.): Peerto-Peer Accommodation Networks: pushing the boundaries. Goodfellow Publishers Ltd, Oxford, $120-136$.

Halvorsen, R. \& Palmquist, R. (1980). The interpretation of dummy variables in semilogarithmic equations. American Economic Review, 70(3), 474-475.

Hamari, J., Sjöklint, M. \& Ukkonen, A. (2016). The sharing economy: Why people participate in collaborative consumption. Journal of the Association Information Science and Technology, 67, 20472059.

Horn, K. \& Merante, M. (2017). Is home sharing driving up rents? Evidence from Airbnb in Boston. Journal of Housing Economics, 38, 14-24.

Hrobath, B. A., Leisch, F. \& Dolnicar, S. (2017). Drivers of Price in City Destination Vienna. In: Dolnicar, S. (ed.): Peer-to-Peer Accommodation Networks: Pushing the boundaries. Goodfellow Publishers Ltd, Oxford, 137-147.

Hung, W-T., Shang, J-K. \& Wang, F-C. (2010). Pricing determinants in the hotel industry: Quantile regression analysis. International Journal of Hospitality Management, 29(3), 378-384.

Jefferson-Jones, J. (2015). Airbnb and the Housing Segment of the Modern "Sharing Economy": Are Short-Term Rental Restrictions an Unconstitutional Taking? Hastings Constitutional Law Quaterly, 42, 557-575.

Kakar, V., Franco, J., Voelz, J. \& Wu, J. (2016). Effects of Host Race Information on Airbnb Listing Prices in San Francisco. MPRA Paper No. 69974. URL: https://mpra.ub.unimuenchen.de/69974/1/MPRA_paper_69974.pdf (Accessed 10.10.2018).

Kaplan, R. A. \& Nadler, M. L. (2015). Airbnb: a case study in occupancy regulation and taxation. The University of Chicago Law Review Dialogue, 82(1), 103-115.

Ke, Q. (2017). Sharing Means Renting? An Entire-marketplace Analysis of Airbnb. Proceedings of the 2017 ACM on Web Science Conference (2017). 131-139.

Kennedy, P. (2008). A guide to Econometrics. Blackwell Publishing.

Kennedy, R. D., Douglas, O., Stehouwer, L. \& Dawson, J. (2018). The availability of smoking-permitted accommodations from Airbnb in 12 Canadian cities. Tobacco Control, 27(1), 112-116.

Koenker, R. (2005). Quantile Regression. Cambridge University Press, New York.

Lee, D. (2016). How Airbnb Short-Term Rentals Exacerbate Los Angeles's Affordable Housing Crisis: Analysis and Policy Recommendations. Harvard Policy and Law Review, 10, 229-253.

Li, H. \& Srinivasan, K. (2018). Competitive Dynamics in the Sharing Economy: An Analysis in the Context of Airbnb and Hotels. URL: http://dx.doi.org/10.2139/ssrn.319769 (Accessed 10.10.2018).

Li, J., Moreno, A. \& Zhang, D. (2016a). Pros vs Joes: Agent Pricing Behavior in the Sharing Economy (August 28, 2016). Ross School of Business Paper No. 1298. URL: http://dx.doi.org/10.2139/ssrn.2708279 (Accessed 10.10.2018).

Li, Y., Pan, Q., Yang, T. \& Guo, L. (2016b). Reasonable Price Recommendation on Airbnb Using MultiScale Clustering. In Proceedings of the 35th Chinese Control Conference. 7038-7041. URL: https://doi.org/10.1109/ChiCC.2016.7554467 (Accessed 10.10.2018).

Lockyer, T. (2015). The perceived importance of price as one hotel selection dimension. Tourism Management, 26(4), 529-537. 
Magno, F., Cassia, F. \& Ugolini, M. (2018). Accommodation prices on Airbnb: effects of host experience and market demand. The TQM Journal, 30(5), 608-620.

Masiero, L., Nicolau, J. L. \& Law, R. (2015). A demand-driven analysis of tourist accommodation price: A quantile regression of room bookings. International Journal of Hospitality Management, 50, 1-8.

Meleo, L., Romolini, A. \& De Marco, M. (2016). The Sharing Economy Revolution and Peer-to-peer Online Platforms. The Case of Airbnb. In: Borangiu, T., Dragoicea, M., Nóvoa, H. (eds): Exploring Services Science. Springer, Cham, 561-570.

Midgett, C., Bendickson, J. S., Muldon, J. \& Solomon, S. J. (2017). The sharing economy and sustainability: A case for Airbnb. Small Business Institute Journal, 13(2), 51-71.

Mody, M. A., Suess, C. \& Lehto, X. (2017). The accommodation experiencescape: a comparative assessment of hotels and Airbnb. International Journal of Contemporary Hospitality Management, 62, 2377-2404.

Möhlmann, M. (2015). Collaborative Consumption: Determinants of satisfaction and the likelihood of using a sharing economy option again. Journal of Consumer Behaviour, 14(3), 193-207.

Mosteller, F. \& Tukey, J. W. (1977). Data analysis and regression. Addison-Wesley Publishing Co, Reading.

Murillo, D., Buckland, H. \& Vai, E. (2017). When the sharing economy becomes neoliberalism on steroids: Unraveling the controversies. Technological Forecasting $\mathcal{E}$ Social Change, 125, 66-76.

Neeser. D., Peitz, M. \& Stuhler, J. (2015). Does Airbnb Hurt Hotel Business: Evidence from the Nordic Countries. URL: https://www.heartland.org/_template-assets/documents/publications/ master_thesis_airbnb.pdf (Accessed 10.10.2018).

OCU (2016). Collaboration or Business? Collaborative Consumption: From Value for users to a Society with Values. OCU Ediciones SA. URL: http://www.oneplanetnetwork.org/sites/default/files/ collaboration_or_business_cc_p2p_2016.pdf (Accessed 10.10.2018).

Olmedilla, M., Martínez-Torres, M.R. \& Toral, S. L. (2016). Harvesting Big Data in social science: A methodological approach for collecting online user-generated content. Computer Standards $\mathcal{E}$ Interfaces, 46, 79-87.

Önder, I., Weismayer, C. \& Gunter, U. (2018). Spatial price dependencies between the traditional accommodation sector and the sharing economy. Tourism Economics, 1-17.

Oskam, J. \& Boswijk, A. (2016). Airbnb: The future of networked hospitality business. Journal of Tourism Futures, 2(1), 22-42.

Perez-Sanchez, V. R., Serrano-Estrada, L., Marti, P. \& Mora-Garcia, R-T. (2018). The what, where, and why of Airbnb price determinants. Sustainability, 10, 1-31.

Pew Research Center (2016). Shared, Collaborative and on Demand: The New Digital Economy. URL: http://www.pewresearch.org/wp-content/uploads/sites/9/2016/o5/PI_2016.05.19_SharingEconomy_FINAL.pdf (Accessed 10.10.2018).

Pizam, A. (2014). Peer-to-peer travel: Blessing or blight? International Journal of Hospitality Management, 38, 118-119.

Puczkó, L. \& Rátz, T. (2000). Tourist and Resident Perceptions of the Physical Impacts of Tourism at Lake Balaton, Hungary: Issues for Sustainable Tourism Management. Journal of Sustainable Tourism, $8(6), 458-478$.

PWC (2015a). Five steps to success in the sharing economy. URL: http://www.pewresearch.org/wpcontent/uploads/sites/9/2016/05/PI_2016.05.19_Sharing-Economy_FINAL.pdf (Accessed10.10.2018).

PWC (2015b). The Sharing Economy. URL: https://www.pwc.com/us/en/industry/entertainmentmedia/publications/consumer-intelligence-series/assets/pwc-cis-sharing-economy.pdf (Accessed 10.10.2018). 
Quattrone, G., Proserpio, D., Quercia, D., Capra, L. \& Musolesi, M. (2016). Who benefits from the "sharing" economy of Airbnb? Proceedings of the 25th International Conference on World Wide Web. 1385-1394.

Ranjbari, M., Morales-Alonso, G. \& Carrasco-Gallego, R. (2018). Conceptualizing the Sharing Economy through Presenting a Comprehensive Framework. Sustainability, 10(7), 1-24.

Rosen, S. (1974). Hedonic prices and implicit markets: product differentiation in pure competition. Journal of Political Economy, 82(1), 34-55.

Samaan, R. (2015). Airbnb, rising rent, and the housing crisis in Los Angeles. URL: http://www.laane.org/wp-content/uploads/2015/o3/AirBnB-Final.pdf (Accessed 10.10.2018).

Schamel, G. (2012). Weekend vs. midweek stays: Modeling hotel room rates in a small market. International Journal of Hospitality Management, 31(4), 1113-1118.

Smith, M. K., Egedy, T., Csizmady, A., Jancsik, A., Olt, G. \& Michalkó, G. (2018). Non-planning and tourism consumption in Budapest's inner city. Tourism Geographies, 20(3), 524-548.

Statista (2018). Leading hotel brands based on brand value worldwide in 2017 (in billion U.S. dollars). URL: $\quad$ https://www.statista.com/statistics/732907/most-valuable-hotel-brands-worldwide/ (Accessed 10.10.2018).

Sung, E., Kim, H. \& Lee, D. (2018). Why Do People Consume and Provide Sharing Economy Accommodation? - A Sustainability Perspective. Sustainability, 10(6), 2-17.

Teubner, T., Hawlitschek, F. \& Dann, D. (2017). Price determinants on Airbnb: How reputation pays off in the sharing economy. Journal of Self-Governance and Management Economics, 5(4), 53-80.

Teubner, T., Saade, N., Hawlitschek, F. \& Weinhardt, C. (2016). It's only pixels, badges, and stars: On the economic value of reputation on Airbnb. Australasian Conference on Information Systems, Wollongong, Australia. URL: https://ro.uow.edu.au/cgi/viewcontent.cgi?article=1055\&context= acis2016 (Accessed 10.10.2018).

Thrane, C. (2007). Examining the determinants of room rates for hotels in capital cities: the Oslo experience. Journal of Revenue and Pricing Management, 5(4), 315-323.

Törzsök, A., Galambos, I., Gonda, T. \& Csapó, J. (2017). A Balaton vendégforgalmának fejlődése a két világháború között. (The Development of Guest Flow at Lake Balaton Between the Two World Wars) Területi Statisztika, 57(6), 665-685.

Tussyadiah, I. P. (2015). An Exploratory Study on Drivers and Deterrents of Collaborative Consumption of Travel. In: Tussyadiah, I. P., Inversini, A. (eds.): Information and Communication Technologies in Tourism 2015. Springer, Cham. 817-830.

Tussyadiah, I. P. \& Pesonen, J. (2016). Impacts of Peer-to-Peer Accommodation Use on Travel Patterns. Journal of Travel Research, 55(8), 1022-1040.

Tussyadiah, I. P. \& Zach, F. (2017). Identifying salient attributes of peer-to-peer accommodation experience. Journal of Travel \& Tourism Marketing, 34(5), 636-652.

Van der Borg, J., Camatti, N., Bertocchi, D. \& Albarea, A. (2017). The Rise of Sharing Economy in Tourism: Airbnb Attributes for the Veneto Region. University Ca' Foscari of Venice, Dept. of Economics Research Paper Series No. 05/WP/2017. URL: http://dx.doi.org/10.2139/ssrn.2997985 (Accessed 10.10.2018).

Wachsmuth, D. \& Weisler, A. (2018). Airbnb and rent gap: Gentrification through the sharing economy. Environment and Planning A, 50(6), 1147-1170.

Wang, C. \& Jeong, M. (2018). What makes you choose Airbnb again? An examination of users' perceptions toward the website and their stay. International Journal of Hospitality Management, 74, 162-170.

Wang, D., Li, M., Guo, P. \& Xu, W. (2016). The impact of sharing economy on the diversification of tourist products: Implication for tourist experience. In: Inversini, A., Schegg, R. (eds.): Information and Communication Technologies in Tourism 2016. Springer, Cham. 695-708. 
Wang, D. \& Nicolau, J. L. (2017). Price determinants of sharing economy based accommodation rental: A study of listings from 33 cities on Airbnb. International Journal of Hospitality Management, 62, 120-131.

Xie, K. L. \& Kwok, L. (2017). The effects of Airbnb's price positioning on hotel performance. International Journal of Hospitality Management, 67, 174-184.

Yang, Y., Mueller, N. J. \& Croes, R. R. (2016). Market accessibility and hotel prices in the Caribbean: The moderating effect of quality-signaling factors. Tourism Management, 56, 40-51.

Zervas, G., Proserpio, D. \& Byers, J. (2017). The Rise of the Sharing Economy: Estimating the Impact of Airbnb on the Hotel Industry. Journal of Marketing Research, 54(5), 687-705.

Zhang, H., Zhang, J., Lu, S., Cheng, S. \& Zhang, J. (2011a). Modeling hotel room price with geographically weighted regression. International Journal of Hospitality Management, 30(4), 1036-1043.

Zhang, Z., Chen, R. J. C., Han, L. D. \& Yang, L. (2017). Key Factors Affecting the Price of Airbnb Listings: A Geographically Weighted Approach. Sustainability, 9(9), 1-13.

Zhang, Z., Ye, Q. \& Law, R. (2011b). Determinants of hotel room price - An exploration of travelers' hierarchy of accommodation needs. International Journal of Contemporary Hospitality Management, 23(7), 972-981.

Received: 28/03/2019

Accepted: 19/o7/2019

Coordinating editor: Stanislav Ivanov 